\title{
From Traditional Management of Mental Illness to Self-Mutilation of the Penile: A Case Report
}

\author{
Barnabé Zango1, Fasnéwindé A. Kaboré1, Moussa Kaboré ${ }^{*}$, \\ Bienvenue D. Ky', Richard W. Ouédraogo², Brahima Kirakoya1, \\ Clôtaire Alexis Marie Kiemdiba Donega Yameogo', Boukary Kabré1, Adama Sanou ${ }^{3}$ \\ ${ }^{1}$ Department of Urology, Yalgado Ouédraogo Teaching Hospital, Ouagadougou, Burkina Faso \\ ${ }^{2}$ Department of Psychiatry, Yalgado Ouédraogo Teaching Hospital, Ouagadougou, Burkina Faso \\ ${ }^{3}$ Division of General Surgery, Yalgado Ouédraogo University Hospital, Ouagadougou, Burkina Faso \\ Email: *kaborem391@yahoo.com
}

Received 26 January 2016; accepted 8 March 2016; published 11 March 2016

Copyright (C) 2016 by authors and Scientific Research Publishing Inc.

This work is licensed under the Creative Commons Attribution International License (CC BY). http://creativecommons.org/licenses/by/4.0/

(c) (i) Open Access

\begin{abstract}
Introduction: Self-mutilation of the external genitalia is rare. It occurs most often on a psychotic ground. Case Report: Mr. P.0. 25-year-old, a dress maker, admitted to the urological emergency for self-section of the penile. The patient had cut his penile with a razor blade and the amputated distal extremity had been thrown in the water closet. The patient was admitted 19 hours after the act of self-harm. Clinical examination had found a stable hemodynamic status, a section of the penile at its root. Psychiatrically schizophrenia evolving for 08 months was diagnosed. An attempt of penile reconstruction was performed. The patient benefited serum and tetanus vaccine, antibiotic and neuroleptics. The parents asked to go home against medical advice the 5th day. Conclusion: The management of self-mutilation of external genitalia is multidisciplinary including surgery and psychiatry.
\end{abstract}

\section{Keywords}

Self-Mutilation, Penile, Schizophrenia, Reconstruction

\section{Introduction}

Self-mutilation of the external genitalia is rare [1]-[3]. It is defined as the willful destruction of the tissues of the "Corresponding author.

How to cite this paper: Zango, B., Kaboré, F.A., Kaboré, M., Ky, B.D., Ouédraogo, R.W., Kirakoya, B., Yameogo, C.A.M.K.D., Kabré, B. and Sanou, A. (2016) From Traditional Management of Mental Illness to Self-Mutilation of the Penile: A Case Report. Open Journal of Urology, 6, 23-26. http://dx.doi.org/10.4236/oju.2016.63005 
external genitalia without conscious intent to die [4]-[7]. Multidisciplinary is the key word in the management of self-harm. The management is surgical but mainly psychiatric. We report a case of self-section of penile in a schizophrenic patient to describe our therapeutic strategy and to bring out the difficulties of a long-term monitoring in the African context.

\section{Case Report}

Mr P.S 25-year-old, a dress maker, admitted to the urological emergency unit of Yalgado Ouédraogo University Hospital of Ouagadougou for self-section of the penile. The patient who lived in a neighboring country would be returned to Burkina Faso to treat psychiatric disorders with a traditional healer. The troubles have been evolving for eight months. For parents, the patient had cut his penile with a razor blade and the amputated distal extremity had been thrown in the water closet. The patient was taken to a clinic where a haemostatic dressing was made and it was referred to the urological emergency unit. We received the patient 19 hours after the act of self-harm. Clinical examination had found a stable hemodynamic status, a section of the penile at its root (Figure 1). Elsewhere there is no wound. Psychiatrically we noted a dissociative syndrome with bizarre behavior. We had noted a delusional syndrome with a delusion of persecution and hallucinatory mechanism. We performed in the surgical room a surgical debridement with an attempt of penile reconstruction. This necessitated a partial mobilization of residual cavernous and spongy body from ischial pubic branches and a section of the suspensory ligament of the penile. He received serum and tetanus vaccine, two antibiotics ceftriaxone and metronidazole. Psychiatrically schizophrenia was diagnosed and the patient received treatment with neuroleptics. But after removal of the catheter on the fith day and resumption of normal urination, parents asked to go home against medical advice (Figure 2). They wanted to continue treatment to the village with the traditional healer. We went to visit the patient in his village after 05 months. He had a normal urination and continued his treatment with prayer groups (Figure 3). We got the family informed consent to publish this study.

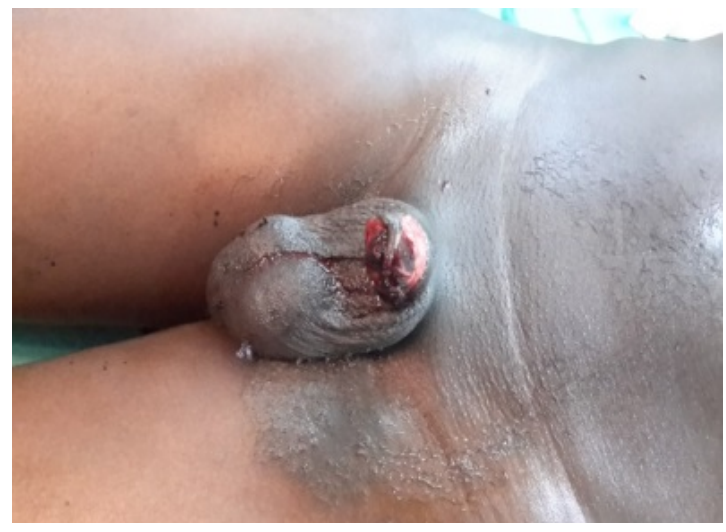

Figure 1. Before surgical debridement.

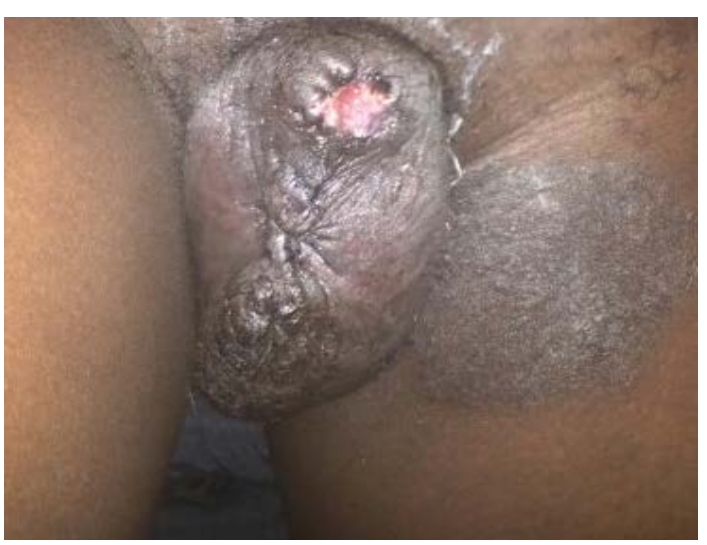

Figure 2. Result on the 5th postoperative day. 


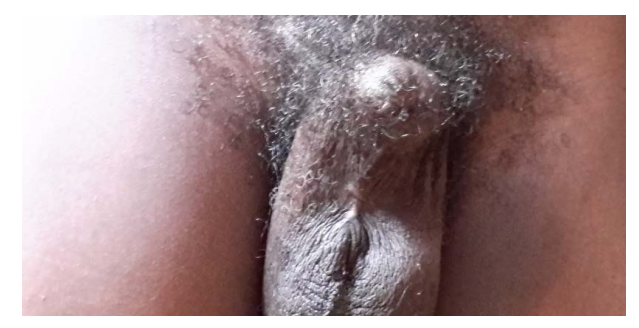

Figure 3. Result after 5 months: We went to visit the patient in his village.

\section{Discussion}

Self-mutilation of the external genitalia is rare [1] [2]. It is a phenomenon which has a predominantly male [1] [5] [7]. The first case of genital self-mutilation was published in English literature by Strock in 1901 [4]. This scarcity is related to the fact that genital mutilation is rarely reported by families [8]-[10]. Usually only the major self-injury is reported. The major self-mutilation occurs mostly on a psychotic field [1] [3] [6]. About $87 \%$ of cases of genital self-mutilation occur in a psychotic context including $51 \%$ of decompensated schizophrenia [11]. Self-harm in the nonpsychotic context is rare [2]. Several factors govern the act of self-harm in the psychotic but what is determinant seems to be feelings of guilt associated with sex drive [1]. The act is due to delusions or feelings of sexual guilt [2]. In our patient, psychiatric disorders such delusions of persecution have evolved for eight months. Living in a world where he would be persecuted, our patient found in self-mutilation a strategy to draw attention to himself because he is a "man persecuted".

In our case penile replantation was not possible because the amputated distal extremity was not available. If penile replantation is possible, it should always be attempted in a better period [8]. We performed then the penile elongation technique by partial mobilization of residual cavernous and spongy body from the ischiopubic branches. The suspensory ligament of the penile was also sectioned. This avoids the perineal urethrostomy. Best results are obtained by this technique both functionally and esthetically. Abdellatif B. et al. reported a case of traumatic amputation of the penis by electricity. Penile reconstruction by mobilizing cavernosa gave good results [12]. It remains alternative when penile replantation which must be made before the $6^{\text {th }}$ hour is impossible because of ischemia and infection risk. However successful penile replantation after the 16th hour was reported and this through microsurgery [3]. So even if the distal extremity of the amputated penile was available, the consultation period for our patient associated with the unavailability of microsurgery would not allow reimplantation.

The management of self-mutilation should be multidisciplinary. Any surgery that will ignore the mental dimension of self-harm would jeopardize success. It would be illusory to perform penile reimplantation in a longtime psychotic patient. Recurrences are frequent. Kaboré F. A. et al. reported a case of a recurrent penile self-amputation on a schizophrenic field [13].

In Africa and particularly in Burkina, traditional healers have an important place in the management of mental illness. The collective unconscious considers mental illness as due to genius and therefore modern medicine can't do anything. Thus the patient is often seen in medical consultation at the stage of decompensation with somatic symptoms. This is the case of our patient. The role of religion is also important. The phenomenon of healing prayers is growing and many patients abandon modern medicine and are turning to these "miracle makers". This is the case of our patient whose parents decided to continue treatment with healers and prayer groups. But very often the last resort remains modern medicine. This makes it very difficult to monitor these patients.

\section{Conclusion}

Self-mutilation of the penile is rare. The management has two components that are complementary: It is urological but mainly psychiatric. Modern medicine and some religious and traditional beliefs should not oppose. We believe they can coexist because the interests of the patient come first.

\section{Conflict of Interest}

None. 


\section{References}

[1] Yadukul, S., Udaya Shankar, B.S. and Shivakumar, B.C. (2014) A Case of Genital Self-Mutilation Committed before Suicide. Egyptian Journal of Forensic Sciences, 5, 70-72.

[2] Tripathi, A., Tekkalaki, B. and Agarwal, A. (2015) Genital Self-Mutilation in a Non-Psychotic Male to Get Rid of Excessive Sexual Drive: A Case Report. South African Journal of Psychiatry, 21, 35-36.

[3] Sarr, A., et al. (2014) Male Genital Self-Mutilation: About Two Cases. Sexologies, 24, 65-68. http://dx.doi.org/10.1016/j.sexol.2014.06.002

[4] Siddiquee, R.A. and Deshpande, S. (2007) A Case of Genital Self-Mutilation in a Patient with Psychosis. German Journal of Psychiatry, 10, 25-28.

[5] Ozan, E., Deveci, E., Oral, M., Yazici, E. and Kirpinar, I. (2010) Male Genital Self-Mutilation as a Psychotic Solution. Israel Journal of Psychiatry and Related Sciences, 47, 297-303.

[6] Shoib, S. (2014) Self-Mutilation of Genitalia Masquerading as Suicide: A Rare Case Report. Journal of Psychiatry, 17, 4.

[7] Kharbach, Y., et al. (2014) Penile Self-Mutilation Preceded by Bizarre Delusions: Two Case Reports. Journal of Medical Case Reports, 8, 246. http://dx.doi.org/10.1186/1752-1947-8-246

[8] Rimtebaye, K., et al. (2015) Total Amputation of the Penile: Report of Three Cases. African Journal of Urology, 21, 76-79.

[9] Moufid, K. (2004) Genital Mutilation: About 3 Cases. Progrès en Urologie, 14, 540-543.

[10] Shirodkar, S.S., Hammad, F. and Qureshi, N.A. (2007) Male Genital Self-Amputation in the Middle East. A Simple Repair by Anterior Urethrostomy. Saudi Medical Journal, 28, 791-793.

[11] Kochakarn, W. (2000) Traumatic Amputation of the Penis. Brazilian Journal of Urology, 26, 385-389.

[12] Benchekroun, A., Jira, H., Kasmaoui, E.H., Ghadouane, M., Nouini, Y. and Faik, M. (2002) Penile Reconstruction after Amputation by Electrocution. Progrès en Urologie, 12, 129-131

[13] Kabore, F.A., Fall, P.A., Diao, B., Fall, B., Odzebe, A., Tfeil, Y.O., et al. (2008) Recurrent Self-Amputation of the Penile in a Schizophrenic Field: About a Case. Andrologie, 18, 224-226. http://dx.doi.org/10.1007/BF03040759 